\title{
PENINGKATAN KEMAMPUAN MOTORIK HALUS ANAK USIA DINI MELALUI KEGIATAN MERONCE MENGGUNAKAN MANIK-MANIK PADA KELOMPOK B2 DI TK AL- HAMID KECAMATAN KAWALU KOTA TASIKMALAYA
}

\author{
Ghina Khansa Khayyirah ${ }^{1}$, Sumardi $^{2}$, Elan $^{3}$, Gilar Gandana ${ }^{4}$ \\ ${ }^{1}$ Program Studi PGPAUD UPI Kampus Tasikmalaya \\ ${ }^{2}$ Program Studi PGPAUD UPI Kampus Tasikmalaya \\ ${ }^{3}$ Program Studi PGPAUD UPI Kampus Tasikmalaya \\ Email : ghinakhansa96@gmail.com
}

(Received: November 2018; Accepted: November 2018; Published: Desember 2018)

\begin{abstract}
Motoric skills are abilities that involve muscles in certain body parts such as fingers. One activity that can improve the motoric skills of early childhood is through meronce activities using beads. This study aims to describe the ability of teachers in planning the learning of motoric skills of early childhood through the activity of meronce in group B2 in TK Al-Hamid, describing the ability of teachers in the process of learning fine motor skills of early childhood through meronce using beads in group B2 in TK Al-Hamid, and describes the teacher's ability to improve the motoric skills of early childhood through meronce using beads in the B2 TK Al-Hamid group. The motoric aspects studied include second-hand motion skills, limb movement skills related to fingers, and skills that are able to coordinate the eyes with the hands. This type of research is Classroom Action Research. With the research model of Kemmis and Mc. Taggart. Data analysis in this study researchers used qualitative data and quantitative data. The subjects in this study were 10 early childhood children from B2 TK TK Al-Hamid group, namely 7 boys and 3 girls. The results of this study indicate that children's motoric skills have increased after being given meronce activities using beads.
\end{abstract}

Keywords: Early Childhood, Motoric Skill, MeronceActivities

\begin{abstract}
ABSTRAK
Kemampuan motorik halus adalah kemampuan yang melibatkan otot-otot pada bagian tubuh tertentu seperti jari tangan. Salah satu kegiatan yang dapat meningkatkan kemampuan motorik halus anak usia dini yaitu melalui kegiatan meronce menggunakan manik-manik. Penelitian ini bertujuan untuk peningkatan kemampuan motorik halus anak usia dini melalui egiatan meronce memnggunakan manik-manik pada kelompok B2 di Tk Al- Hamid Kecamatan Kawalu Kota Tasikmalaya. Aspek motorik halus yang diteliti antara lain, keterampil dalam menggunkan jari-jemari tangan untuk melakukan aktivitas, terampil dalam menggerakkan jari-jemari tangan, terampil dalam mengerakan kedua tangan, pengendalian gerak, melakukan gerakan terkoordinasi terkontro, terampil dalam kecermatan dan ketepatan.. Jenis penelitian ini yaitu Penelitian Tindakan Kelas. Dengan model penelitian Kemmis dan Mc. Taggart. Analisis data dalam penelitian ini peneliti menggunakan data kualitatif dan data kuantitatif. Subjek dalam penelitian ini adalah anak usia dini kelompok B2 Tk Al- Hamid berjumlah 10 orang, yaitu 6 orang anak laki-laki dan 4 orang anak perempuan. Hasil penelitian ini menunjukan bahwa kemampuan motorik halus anak mengalami peningkatan setelah diberikan kegiatan meronce menggunakan manik-manik.
\end{abstract}

Kata kunci : Anak Usia Dini, Motorik Halus, Meronce 


\section{PENDAHULUAN}

Sujiono, (2013, hlm.6) menyatakan "Anak usia dini adalah sosok individu yang sedang menjalani suatu proses perkembangan dengan pesat dan fundamental bagi kehidupan selanjutnya".

Anak usia dini memiliki otak dua kali lebih aktif dibandingkan dengan orang dewasa. Dengan demikian otak anak mampu menyerap informasi dengan cepat dibandingkan dengan orang dewasa. Maka dari itu anak diperlukan stimulus atau rangsangan yang sesuai dengan tahap perkembangannya. Seperti yang di paparkan oleh Suyadi dan Ulfah (2016, hlm. 3) "Ketika lahir sel-sel otak bayi berjumlah sekitar 100 miliar, tetapi belum saling berhubungan kecuali hanya sedikit, yaitu hanya sel-sel otak yang mengendalikan detak jantung, pernafasan, gerak refleks, pendengaran, dan naluri hidup. Saat anak usia 3 tahun otak anak bagaikan spons yang siap menyerap apapun yang dirangsang oleh lingkungan sekitarnya. Oleh karena itu, diperlukan beragam stimulus atau rangsangan berupa suara (lagu/nada), gambar, bentuk dan lain-lain. perkembangan intelektual, sosial emosional, bahasa dan juga seni. Namun, jika kita salah dalam memberikan arahan dan bimbingan maka akan memberikan dampak negatif dalam jangka panjang dan sulit untuk diperbaiki.

Undang-undang Sistem Pendidikan Nasional No. 20 Tahun 2003 adalah kelompok manusia yang berusia 0 sampai dengan 6 tahun. Anak Usia Dini merupakan kelompok anak yang berada dalam proses pertumbuhan dan perkembangan yang bersifat unik, artinya memiliki pola pertumbuhan dan perkembangan yang terdapat 6 (enam) aspek perkembangan anak usia dini, yaitu kesadaran personal, kesehatan emosional, sosialisasi, komunikasi, koginisi dan keterampilandan keteramipilan motorik. Oleh karena itu para pendidik sudah seharusnya memberikan perhatian dan perlakuan yang tepat kepada anak prasekolah sesuai dengan tahap perkembangannya.

Salah satu perkembangan yang ada pada pendidikkan anak usia dini yaitu perkembangan motorik.

Menurut Beaty (2013, hlm. 236) menyatakan bahwa "Motorik halus merupakan perkembangan melibatkan otot-otot halus yang melibatlan tangan dan mata". Kemampuan motorik halus merupakan kemampuan yang melibatkan otot-otot kecil atau kemampuan yang melibatkan otototot halus pada bagian tubuh tertentu seperti jari tangan yang digunakan untuk menulis, meremas dan menggenggam.

Anak Usia 5-6 tahun diharapkan telah mampu menguasai beberapa kemampuan motorik halus, seperti menggambar sesuai gagasannya, meniru bentuk, melakukan eksplorasi dengan berbagai media dan kegiatan, menggunakan alat tulis dan alat makan dengan benar, menggunting sesuai dengan pola, menempel gambar dengan tepat, dan mengekspresikan diri melalui gerakan menggambar secara rinci (Permendikbud Nomor 137 Tahun 2014).

Salah satu kegiatan yang tepat dalam meningkatkan montorik halus yaitu kegiatan meronce. Karena kegiatan meronce melibatkan tangan dan mata. Menggunakkan kegiatan meronce juga dapat menstimulus ketangkasan dalam menggunakan jari jemari.

Meronce merupakkan pekerjaan yang mencerminkan wujud penghargaan terhadap keindahan benda-benda alam. Meronce adalah teknik membuat benda pakai/hias dari bahan mank-manik, biji-bijian atau bahan lain yang dapat dilubangi dengan alat tusuk sehingga dapat dipakai. Meronce dalam proses pembelajaran anak usia dini dapat 
melatih anak berkonsentrasi. Aktivitas meronce memiliki kelebihan diantaranya: meronce mampu mengasah kemampuan kognitif anak, sebagai sarana menyiapkan anak membaca, dan melatih ketelitian anak. Meronce juga bermanfaat untuk melatih imajinasi anak melalui bentuk dan bahan. Dengan meronce dapat melatih ketelitian melalui kecermatan merangkai serta menyusun benda dan menyatakan keinginan terhadap benda yang di minta. (Pamadhi dan Sukan, 2015, hlm. 13).

Dengan demikian kegiatan meronce dapat mendorong anak untuk mengembangkan daya cipta yang ada di dalam dirinya. Kemampuan dalam motorik halus anak dapat mengembangkan otot-otot jari tangan.

Oleh karena itu anak seharunya diberi kesempatan untuk meronce sehingga gerakannya dapat diperhalus melalui pengulangan dan latihan.

Memurut Observasi dan wawancara yang dilakukan di TK AlHamid Kelurahan Gunung Gede Kecamatan Kawalu Kota Tasikmalaya, anak-anak kurang terampil dalam mengembangkan motorik halus dalam kegiatan meronce. Mengekspresikan diri dan berkreasi dengan berbagai idea tau gagasan dengan menggunakan manikmanik menjadi suatu karya seni yang bertujuan untuk meningkatkan motorik halus anak melalui kegiatan meronce. Dengan kegiatan ini anak dapat menyalurkan perasaan dan menicptakan keindahan. Kegiatan akan dilaksanakan kegiatan apa yang akan dilakukan bersama anak-anak dikelas

Berdasarkan uraian diatas, penulis akan meneliti dan mengamati proses pembelajaran yang akan dilakukan dengan judul "Peningkatkan Motorik Halus Anak melalui Kegitan Meronce Menggunakan Manik-manik di Kelompok B2 TK Al- Hamid Kecamatan Kawalu Kota Tasikmalaya".
Menurut hasil observasi dan wawancara, pada kenyataanya di TK AlHmaid Kecamatan Kawalu Kota Tasikmalaya sebagian besar dari jumlah anak kemampuan motorik halus nya masih rendah, terlihat dari anak yang masih belum bisa memasukkan tali sepatu kedalam lubang, dan ketika anak memegang pensil.

Berdasarkan permasalahan di atas maka penulis mempunyai alternatif untuk melakukan penelitian tindakan kelas (PTK) yaitu peningkatan kemampuan motorik halus melalui kegiatan meronce menggunakan manik-manik. Kegiatan meronce merupakan salah satu kegiatan yang berkaitan dnegan motoik halus dalam pendidikan anak usia dini. Denegan dilakukannya kegiatan motorik halus melalui kegiatan mronce menggunakan manik-manik maka anak dapat melatih kelenturan jari-jemari dan juga dapat memfokuskan pandangan pada saat memasukkan bahan meronce ke dalam benang. Hal ini diperkuat dengan peneliti Bakti Arum Mumpuni yang berjudul Peningkatan Keterampilan Motorik Halus Melalui Kegiatan Meronce Menggunakan Bahan Tanah Liat Pada Kelompok B TK Yayasan MAsyithoh Beran Bugel Kulon Progo Tahun .

Sumanto (dalam Bakti 2014 hlm. 30) Meronce adalah pembuatan benda hias atau benda pakai yang dilakukan dengan menyusun bagianbagian bahan berlubang atau sengaja dilubangi memakai bantuan benang, tali dan sejenisnya (Sumanto dalam Bakti ).

Berangkat dari pemikiran di atas, peneliti terdorong untuk melakukan penelitian mengenai perkembangan motorik halus anak melalui kegiatan meronce menggunakan manik-manik pada kelompok B2 Tk Al- Hamid Kecamaatn Kawalu Kota Tasikmalaya.

\section{TINJAUAN PUSTAKA}

Menurut National Association for the Education Young Children (NAEYC) dalam Susanto (2017, hlm. 1) "Anak usia dini (early childhood) merupakan yang berada pada usia nol sampai dengan delapan tahun. Pada masa tersebut merupakan proses pertumbuhan dan perkembangan dalam 
berbagai aspek dalam rentang kehidupan manusia.

Dari pendapat di atas, maka dapat disimpulkan anak usia dini adalah sosok individu yang masa kemampuan dan perkembangannya harus tercapai baik itu dalam kemampuan kognitif maupun psikomotor juga sosialnya. Oleh karena itu kita sebagai orang tua harus memberikan stimulus yang tepat sesuai dengan usia dan perkembangannya.

Santrock (dalam Soetjiningsih 2012, Hlm. 2) mengemukakan bahwa 'perkembangan adalah pola perubahan yang dimulai sejak pembuahan dan terus berlanjut di sepanjang rentang kehidupan individu'.

Seperti yang dipaparkan di atas, dapat disimpulkan bahwa perkembangan motorik halus anak meliputi : nilai moral agama, fisikmotorik, kognitif, bahasa, sosialemosiaonal, serta seni. Semua aspek tersebut harus dapat terpenuhi oleh anak usia dini. Salah satunya aspek perkembangan motorik, oleh karena itu peneliti lebih fokus kepada perkembangan motorik.

Corbin dalam Ms Sumantri (2005, Hlm. 48) berpendapat bahwa perkembangan motorik adalah perbahan kemampuan gerak dari bayi sampai dewasa yang melibatkan motorik meliputi perkembangan otot kasar atau gross muscle dan otot halus atau fine muscle yang sekarang umumnya disebut motorik kasar dan motorik halus.

Dapat disimpulkan dari beberapa para ahli di atas bahwa perkembangan motorik adalah kemampuan gerak melalui otot besar dan otot halus di bagian-bagian tubuh. Perkembangan motorik meliputi motorik halus dan motorik kasar. Dalam penelitia ini peneliti lebih fokus kepada kemampuan motorik halus.

Menurut Mahendra (dalam Endayanti 2013 hlm. 20) kemampuan motorik halus merupakan keterampilan-keterampilan yang memerlukan kemampuan untuk mengontrol otot-otot kecil atau halus untuk mencapai pelaksanaan keterampilan yang berhasil. Pendapat dari berbagai pihak tersebut, dapat disimpulkan bahwa kemampuan motorik halus adalah keadaan di mana anak mampu melakukan gerakan melalui penggunaan otot-otot kecil atau anggota tubuh tertentu dengan kecermatan dan koordinasi yang baik seperti keterampilan menggunakan tangan.

Perkembangan motorik halus anak pada usia 5-6 tahun sudah dapat menguasai beberapa kemampuan motorik halus anak, seperti menggambar sesuai gagasannya, meniru bentuk, melakukan eksplorasi dengan berbagai media dan kegiatan, menggunakan alat tulis dan alat makan dengan benar, menggunting sesuai dengan pola, menempel gambar dengan tepat, dan mengekspresikan diri melalui gerakan menggambar secara rinci (Permendikbud Nomor 137 Tahun 2014).

Dapat disimpulkan bahwa gerakkan motorik halus adalah gerakkan yang hanya melibatkan otototot kecil. seperti keterampilan menggunakan jari jemari dan gerakkan pergelangan tangan , mampu mengkoordinasikan mata dengan tangan, serta mampu mengendalikan emosi saat melakukan kegiatan yang berhubungan dengan motorik halus. Maka dari itu sesuai dengan uraian di atas peneliti memasukkannya pada kisi-kisi instrumen penelitian ini.

Effiana Yuriastien, dkk (2009, hlm. 193) menyatakan bahwa ada beberapa manfaat dalam meronce, yaitu:

1. Membantu kemampuan motorik halus. Saat anak melakukkan kegiatan meronce anak mengambil butan tanah liat dan memasukkannya ke dalamkubang dengan menggunakan tali. 
2. Melatih kooridnasi mata dengan tangan. Anak menggunakan kedua tanngan dan tangan.

3. Meningkatan perhatian dan konsentrasi. Pada saat meronce, anak membutuhkan latian dan konestrasi saat memasukkan koordinasi mata dan tangan

Adapun aspek meronce menurt Pamadhi Hajar dari Sukardi Evan (2014, hlm. 15):

1. Permainan, merangkai maupun meronce dapat berfungsi untuk alat bermain anak, berbenda-benda yang akan dirangkai tidak diyunjukkan untuk kebutuhan tertentu melainkan untuk latihn memperoleh yang rasa dan memahami keindahan.

2. Kreasi dan komposisi, merangkai maupun meronce dapat berfungsi untuk alat bermain anak, bendabenda yang akan dirangkai ditujukkan untuk kebutuhan tertentu melainkan untuk latihan memperoleh rasa dan memhami keindahan

3. Keindahan, aspek keindahan meronce terletak pada cara menyusun benda-benda sebagai komponen rangkaian perhatian

4. Kerajinan dan ketekunan , menuntut kelatihan yaitu usaha memberikkan pelatihan menyusus, menatya dalam bentuk rangkaian yang sesuai dengan rancangan dan tidak mudah rusak susunannya.

Berdasarkan uraian di atas dapat disimpukan bahwa meronce dapat membantu meningkatkan kemampuan motorik halus anak usia dini. Dengan meronce dapat melatih kooridinasi antara mata dan tangan dan juga dapat meningkatkan konsntrasi anak karena saat kegiatan meronce butuh kefokusan yang lebih pada saat memasukkan bahan meronce kedalam benang atau tali. Maka dari itu dalam penelitian ini peneliti memilih kegiatn meronce untuk meningkatkan kemampuan motorik halus.

\section{METODE}

Desaim penelitian yang dilakukkan yaitu Penelitian Tindakkan
Kelas (PTK). Bahri dalam Arifah (2017:23) "Penelitian tindakkan kelas merupakan sebuah kegiatan yang dilaksankan untuk mengamati kejadian-kejadian dalam kelas untuk memperbaiki praktik dalam pembelajaran agar lebih berkualitas dalam proses sehingga hasil belajar pun menjadi lebih baik".

Dari penelitian tersebut dapat disimpulkan bahwa penelitian tindakkan kelas merupakkan pencermatan terhadap kegiatan atau kejadian-kejadian yag terjadi di kelas.

Desain penelitian yang dilakukan yaitu Penelitian Tindakan Kelas (PTK). Menurut (Trianto, 2011, hal. 13) "penelitian tindakan kelas berasal dari istilah bahasa inggris Classroom Action Research, yang berarti penelitian yang dilakukan pada sebuah kelas untuk mengetahui akibat tindakan yang diterapkan pada subjek penelitian di kelas tersebut". Desain model penelitian diambil dari model Kemmis dan Mc. Taggart.

Data adalah hasil pencatatan peneliti baik yang berupa fakta maupun nama bilangan, sedangkan sumber data dalam penelitian adalah subjek dari mana data dapat diperoleh (Arikunto, 2013, hlm.161). Dalam penelitian ini, pengambilan data berasal dari observasi dan catatan lapangan di TK Al- Hamid Kecamatan Kawalu Kota Tasikmalaya. data primer diperoleh dari sumber data pertama (subjek atau objek penelitian) yang langsung diambil. Sumber data premier pada openelitian ini adalah guru dan murid dari TK Al- Hamid. Data sekunder diambil dari data yang sudah ada sebelumnya, data sekunder ini di ambil dari TK Al- Hamid Kecamatan Kawalu Kota Tasikmalaya. Data ini Ipada umumnya di dapat dari hasil wawancara dan bersifat subjektif karena data tersebuyt sesuai dengan penafsiran seseoraang yang berbeda

Menurut Sugiyono (2015, hlm. 243) mengemukkan bahwa "dalam penelitian kuantitatif, teknik analisis data yang digunakkan sudah jelas, yaitu diarahkan untuk menjawab rumusan masalah atau menguji 
hipotesis yang telah dirumuskan dalam proposal.

Data adalah bahan mentah yang harus di olah dan menghasilkan suatu informasi, fakta yang akurat. Jenis data terbagi menjadi dua yaitu kualitatif dan kuantitatif. Dalam penelitian ini, peneliti menggunakan data kualitatif dan data kuantitatif. Data yang diperoleh yaitu data kualitatif dan kuantitatif.

Penelitian ini di lakukkan secara kolaboratif, yaitu hubungan antara peneliti dan guru, permasalahan yang nantinya dapat dipecahkan bersama dan disolusiakan bersama.

Penelitian Tindakkan Kelas yang digunakkan dalam penalitian ini yaitu model Kemmis dan Taggart dalam Arifah (2017:216) penelitian ini dilaksanakan 3 siklus. Setiap siklus memiliki 4 tahapan, yaitu: perencanaan, (2) tindakkan, pengamatan, (4) refleksi

Menurut Dimayati (2013) dalam Fauziyah (2017, hlm.40) sumber data ialah 'subjek penelitian dimana darinya akan diperoleh data.' Adapun sumber data dalam penelitian ini adalah : $\mathrm{RPPH}$ ( Rancangan Pelaksanaan Pembelajaran Harian), Guru, dan Anak Usia Dini di Kelompok 2 Tk Al- Hamid.

Teknik pengumpulan data yang digunakan dalam penelitian ini yaitu : Observasi, Catatan Lapangan, Wawancara, Tes Kinerja, Dokumentasi.

Menurut Sugiyono (2015, hlm. 147) analisis data merupakan kegiatan setelah data atau sumber data lain terkumpul. Kegiatan dalam analisis data adalah : mengelompokan data berdasarkan jenis variabel dan responden, mentabulasi data berdasarkan variabel dari seluruh responden, menyajikan data dari tiap variabel yang diteliti, melakukan perhitungan untuk menjawab rumusan masalah.Teknik analisis data yang digunakan dalam penelitian ini adalah teknik analisis deskriptif kuantitatif. Adapun tata cara penghitungan skor melalui instrumen chek list dan LKA (Lembar Kerja Anak) mengenai kemampuan motorik halus anak usia dini melalui kolase berbahan serbuk kayu. Adapun rumus penghitungan persentase yang diperoleh adalah sebagai berikut :

$$
\mathrm{NP}=\frac{R}{S M} \mathrm{X} 100 \%
$$

Keterangan : NP = Nilai persen yang dicari atau diharapkan, $\mathrm{R}=$ Skor mentah yang diperoleh, $\mathrm{SM}=$ Skor maksimal ideal dari tes yang bersangkutan, $100=$ Bilangan tetap.

Sedangkan untuk menilai kemampuan guru dalam merencanakan pembelajaran, pelaksanaan pembelajaran, serta kegiatan peningkatan kemampuan motorik halus anak, peneliti menggunakan penilaian yang sama dengan penilaian anak, yaitu diadaptasi oleh Djamarah dan Zain.

\section{HASIL DAN PEMBAHASAN}

Penelitian tindakan kelas yang telah dilaksanakan terdiri dari tiga siklus. Pelaksanaan pada siklus I berlangsung pada tanggal 17 Mei 2018, pelaksanaan pada siklus II pada tanggal 21 Mei 2018, dan pelaksanaan siklus III pada tanggal 28 Mei 2018. Penelitian ini yaitu kegiatan meronce menggunakan manik-manik untuk meningkatkan kemampuan motorik halus anak usia dini pada kelompok B2 Tk- Hamid Kecamatan Kawalu Kota Tasikmalaya.

\subsection{Kemampuan Guru dalam Merencanakan Pembelajaran}

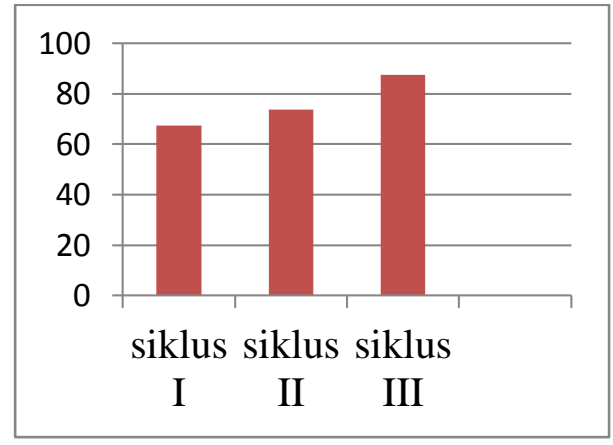

Gambar 4.1

Diagram Perubahan Siklus I - Siklus III Kemampuan Guru dalam Perencanaan Pembelajaran

Kemampuan guru dalam merencanakan pembelajaran pada penelitian tindakan kelas (PTK) ini dituangkan dalam tiga buah rencana pelaksanaan pembelajaran harian (RPPH). Pada tiga siklus tindakan, peningkatan kemampuan guru dalam merencanakan pembelajaran harian adalah sebagai berikut : pada siklus I jumlah skor yang diperoleh guru dalam membuat perencanaan pembelajaran harian adalah 10,8 dengan persentase $67,58 \%$ jumlah tersebut belum mencapai indikator keberhasilan yang telah ditentukan. Kelemahan pada perencanaan 
pembelajaran harian pada siklus I yaitu pengembangan tema/sub tema dan penentuan metode yang dipilih kurang tepat sehingga berpengaruh terhadap proses pembelajaran. Pada siklus II mengalami peningkatan sebesar 0,25 dengan persentase $6,3 \%$ jumlah skor menjadi 11,8 dengan persentase $73,8 \%$. Kelemahan pada siklus II yaitu pemanfaatan media pembelajaran sesuai dengan bidang pengembangan.. Pada siklus III kekurangan tersebut dapat diatasi dan mengalami peningkatan sebesar 0,55 dengan persentase $13,7 \%$ jadi pada siklus III jumlah skor menjadi 14,1 dengan persentase $87,5 \%$. Jadi peningkatan tertinggi terdapat pada siklus II ke siklus III yaitu sebesar 0,55 dengan persentase $13,7 \%$. Hal ini terjadi karena pada siklus III upaya guru dalam memperbaiki Rencana Pelaksanaan Pembelajaran Harian dilakukan dengan optimal.

\subsection{Kemampuan Guru dalam Proses} Pembelajaran

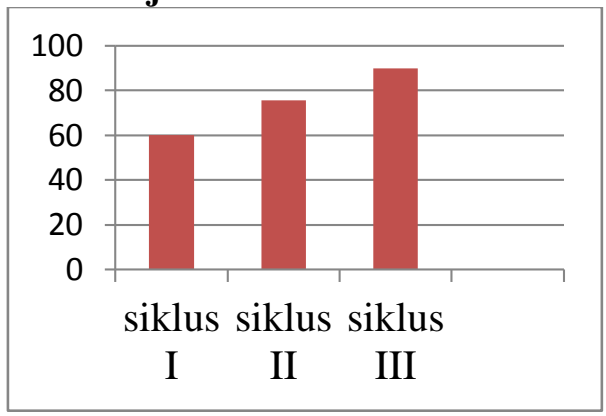

Gambar 4.2

Diagram Perubahan Siklus I - Siklus III Kemampuan Guru dalam Proses Pembelajaran

Kemampuan guru dalam proses pembelajaran yaitu kegiatan Meronce menggunakan manik-manik untuk meningkatkan kemampuan motorik halus anak usia dini. Kemampuan peneliti dalam melaksanakan kegiatan pembelajaran pada siklus I mencapai 7,1 dengan persentase $60 \%$. Ada beberapa aspek yang harus diperbaiki yaitu : a. Memeriksa kesiapan siswa, b. Melakukan kegiatan apresiasi, c. Penguasaan materi pembelajaran, $d$. Pendekatan/strategi pembelajaran, e. Pemanfaatan ssumber belajar/media pembelajaran, f. Pembelajaran yang memicu dan memelihara keterlibatan siswa, g. Penilaian proses dan hasil belajar, h. Melakukan refleksi dengan melibatkan siswa, i. Melaksanakan tindak lanjut dengan memberikan arahan. Pada siklus II kelemahankelemahan peneliti mulai diperbaiki, dan kemampuan melaksanakan kegiatan mengalami peningkatan sebesar 0,5 dengan persentase $12,5 \%$, menjadi 8,8 dengan presentase $72,5 \%$. Pada siklus II sudah mencapai tingkat pencapaian namun penelitian masih tetapi dilanjutkan pada siklus III karena kemampuan motorik halus anak masih belum berkembang. Pada siklus III kelemahan-kelemahan sudah diperbaiki, kemampuan melaksanakan kegiatan pembelajaran mengalami peningkatan sebesar 0,7 dengan persentase $17,5 \%$ sehingga jumlah skor pada siklus III menjadi 10,8 dengan persentase $90 \%$. Sehingga dapat dinyatakan bahwa peningkatan kemampuan melaksanakan pembelajaran tertinggi yaitu siklus II ke siklus III mengalami peningkatan sebesar 0,7 dengan persentase $17,5 \%$.

\subsection{Kemampuan Guru dalam \\ Meningkatkan Kemapuan Motorik Halus Anak melalui Meronce Menggunakan Manik-manik}

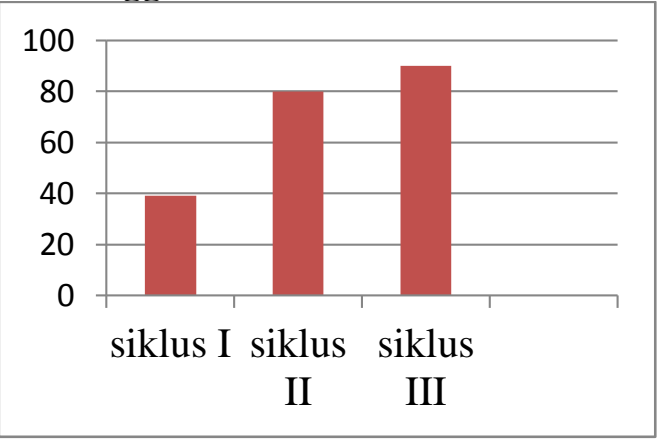

Gambar 4.3

Diagram Perubahan Siklus I - Siklus III

Kemampuan Guru dalam Peningkatan

Kemampuan Motorik Halus Anak Usia

Dini melalui Kegiatan Meronce

Menggunakan Manik-Manik

Dalam kemampuan guru dalam meningkatkan kemampuan motorik halus melalui kegiatan meronce menggunakan manik-manik pada siklus I sebesar 22 dengan persentase 39\% masih terdapat banyak kekurangan dan masih perlu di perbaiki di siklus II. Pada siklus II kelemahan kemampuan guru mulai diperbaiki, dan mengalami peningkatan sebesar 23 dengan persentase $41 \%$ sehingga jumlah skor pada siklus II menjadi 45 dengan persentase $80 \%$. Pada siklus III 
mengalami peningkatan sebesar 7 dengan persentase $13 \%$ sehingga jumlah skor pada siklus III menjadi 52 dengan persentase $93 \%$. Terlihat bahwa meningkatan guru dalam peningkatan motorik halus anak melalui kegiatan meronce menggunakan manik-manik dengan gain (rentang) tertinggi adalah siklus I ke siklus II yaitu mengalami peningkatan sebesar 23 dengan persentae $41 \%$.

\subsection{Peningkatan Kemampuan Motorik Halus Anak Usia Dini}

Kemampuan motorik halus anak usia dini dari kondisi awal sampai siklus III mengalami peningkatan

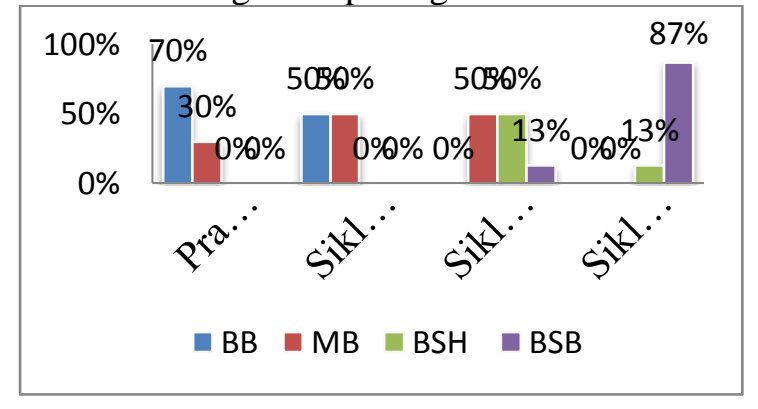

Gambar 4.4

Diagram Perubahan Pra Tindakan - Siklus III Indikator Terampil Dalam Menggerakkan Jarijemari Tangan Untuk Melakukkan Aktivitas

Dari diagram 4.1. dapat diketahui kriteria BB (Belum berkembang) pada kondisi awal sebesar $70 \%$ (7 orang anak), sedangkan pada siklus I sebesar 50\% (5 orang anak), pada siklus II dan III tidak ada satupun kriteria BB (Belum berkembang). Kriteria MB (Masih berkembang) pada kondisi awal sebesar 30\% (3 orang anak), sedangkan pada siklus I sebesar $50 \%$ (5 orang anak), pada siklus II sebesar $50 \%$ (5 orang anak), dan pada siklus III tidak ada satupun aspek MB (Masih berkembang). Kriteria BSH (Berkembang sesuai harapan) tidak ada satupun pada kondisi awal dan siklus I, siklus II sebesar 50\% (5 orang anak), dan pada siklus III sebesar 20\% (2 orang anak). pada kondisi awal, dan siklus I dan II tidak ada satupun kriteria BSB (Berkembang sangat baik), pada siklus III sebesar $80 \%$ (8 orang anak). dari data tersebut terlihat bahwa kemampuan motorik halus anak usia dini pada indikator terampil dalam menggunakan jari-jemari melakukkan aktivitas. Hal tersebut terlihat dari perubahan tiap kriteria, dari BB (Belum berkembang) sebagian berpindah menjadi MB (Masih berkembang) meskipun masih ada anak yang kriteria BB (Belum berkembang), dari MB (Masih berkembang) berpindah menjadi BSH (Berkembang sesuai harapan) meskipun masih ada anak yang kriteria MB (Masih berkembang), kriteria BSH (Berkembang sesuai harapan) berpindah menjadi BSB (berkembang sesuai harapan) sehingga pada siklus III semua anak sudah mencapai kriteria BSH (Berkembang sesuai harapan) dan BSB (Berkembang sangat baik).

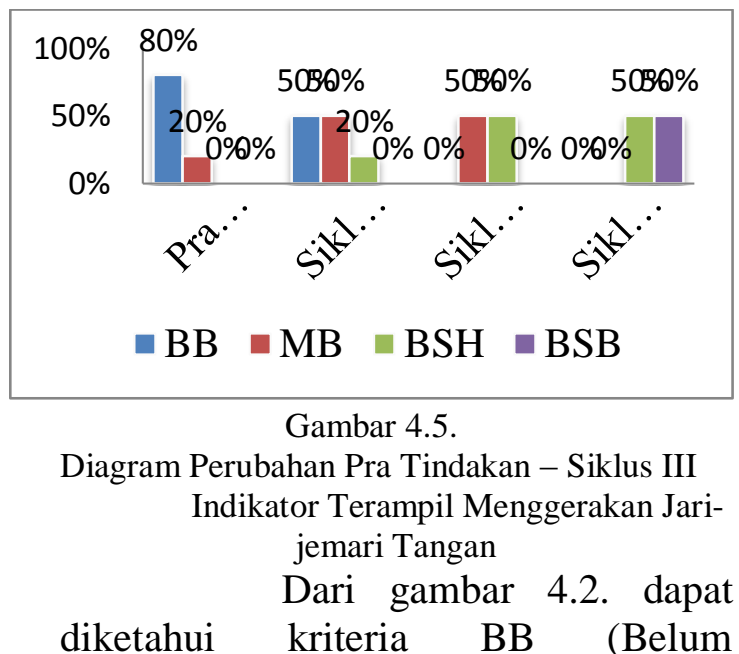

berkembang) pada kondisi awal sebesar $80 \%$ (8 orang anak), pada siklus I sebesar $50 \%$ (5 orang anak), pada siklus II dan siklus III tidak ada satupun kriteria BB (Belum berkembang). Kriteria MB (Masih berkembang) pada kondisi awal ssebesar 20\% (2 orang anak), siklus I sebesar 50\% (5 orang anak), siklus II sebesar 50\% (5 orang anak), dan pada siklus III tidak ada satupun kriteria MB (Masih berkembang. Pada kondisi awal, siklus I, siklus III tidak ada satupun Kriteria BSH (Berkembang sesuai harapan), sedangkan pada siklus II sebesar 50\% (5 orang anak), pada kondisi awal, siklus I, dan siklus II tidak ada satupun kriteria BSB (Berkembang sangat baik), pada siklus III sebesar 100\% (10 orang anak). Dari data tersebut kemampuan motorik halus anak dalam indikator terampil dalam menggerakkan jemari tangan kegiatan ini mengalami peningkatan. Hal tersebut terlihat dari perubahan tiap kriteria, dari BB (Belum berkembang) sebagian berpindah 
menjadi MB (Masih berkembang) meskipun masih ada anak yang kriteria BB (Belum berkembang), dari MB (Masih berkembang) berpindah menjadi BSH (Berkembang sesuai harapan), kriteria BSH (Berkembang sesuai harapan) berpindah menjadi BSB (berkembang sesuai harapan) sehingga pada siklus III semua anak sudah mencapai kriteria BSH (Berkembang sesuai harapan) dan BSB (Berkembang sangat baik).

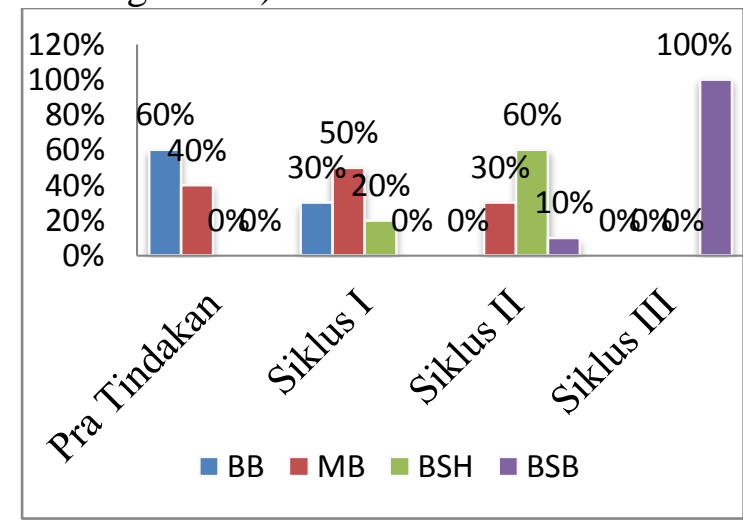

Gambar 4.6

Diagram Perubahan Pra Tindakan - Siklus III Indikator Terampil dalam Menggerakan Kedua Tangan

Dari gambar 4.3. dapat diketahui kriteria BB (Belum berkembang) pada kondisi awal sebesar 60\% (6 orang anak), siklus I sebesar 30\% (3 orang anak), siklus II dan siklus III tidak ada satupun kriteria BB (Belum berkembang). Kriteria MB (Masih berkembang) pada kondisi awal sebesar $40 \%$ (4 orang anak), siklus I sebesar $70 \%$ (7 orang anak), siklus II sebesar30\% (3 orang anak), dan pada siklus III tidak ada satupun kriteria MB (Masih berkembang). Kriteria BSH (Berkembang sesuai harapan) pada kondisi awal, siklus I, dan siklus III tidak ada satupun, sedangkan di siklus II sebesar $60 \%$ (6 orang anak). Kriteria BSB (Berkembang sangat baik) pada kondisi awal, siklus I , siklus II tidak ada satupun kriteria BSB (Berkembang sangat baik), siklus II sebesar 10\% (1 orang anak), dan siklus III sebesar $100 \%$ (10 orang anak). Dari data tersebut kemampuan motorik halus anak usia dini pada indikator terampil menggerakan kedua tangan dalam melakukan aktivitas mengalami peningkatan. Hal tersebut terlihat dari perubahan tiap kriteria, dari BB (Belum berkembang) sebagian berpindah menjadi MB (Masih berkembang) meskipun masih ada anak yang kriteria BB (Belum berkembang), dari MB (Masih berkembang) berpindah menjadi BSH (Berkembang sesuai harapan), kriteria BSH (Berkembang sesuai harapan) berpindah menjadi BSB (berkembang sesuai harapan) sehingga pada siklus III semua anak sudah mencapai kriteria BSB (Berkembang sangat Baik).

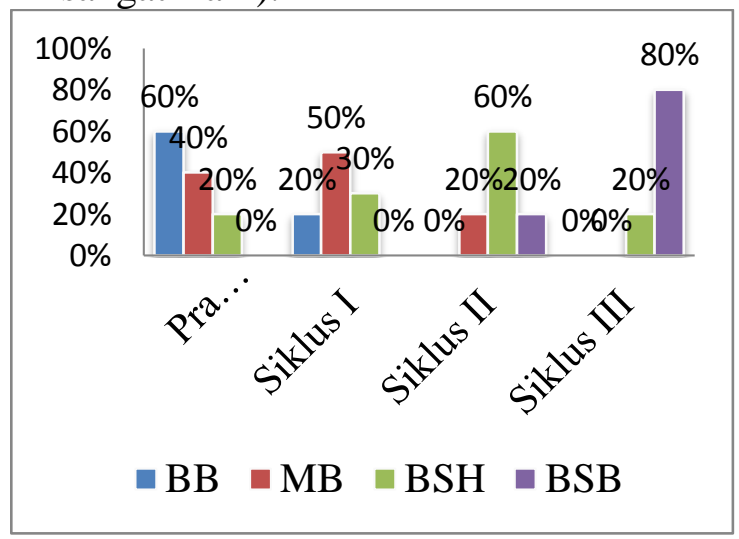

Gambar 4.7.

Diagram Perubahan Pra Tindakan - Siklus III Indikator Terampil Dalam Pengendalian Gerak

Dari gambar 4.4. dapat diketahui kriteria BB (belum berkembang) pada kondisi awal sebesar $60 \%$ (6 orang anak) siklus I sebesar $20 \%$ (2 orang anak), siklus II dan siklus III tidak ada satupun kriteria BB (Belum berkembang). Kriteria MB (Mulai berkembang) pada kondisi awal sebesar $40 \%$ (4 orang anak), siklus I sebesar $50 \%$ (5 orang anak), siklus II sebesar $20 \%$ dan III tidak ada satupun kriteria MB (Masih berkembang), kriteria BSH (Berkembang sesuai harapan) pada kondisi awal tidak satupun kriteria BSH (Berkembang Sesuai Harapan), sedangkan siklus I sebsar 30\% (3 orang anak), siklus II sebesar $60 \%$ ( 6 orang anak), dan pada siklus III sebesar 20\% (2 orang anak). Kriteria BSB (Berkembang sangat baik) pada kondisi awal dan siklus I tidak ada satupun kriteria BSB (Berkemabang Sangat Baik), siklus II sebesar 20\% (2 orang anak), dan siklus III sebesar $80 \%$ (8orang anak).. Hal tersebut terlihat dari perubahan tiap kriteria, dari BB (Belum berkembang) sebagian berpindah 
menjadi MB (Masih berkembang) meskipun masih ada anak yang kriteria BB (Belum berkembang), dari MB (Masih berkembang) berpindah menjadi BSH (Berkembang sesuai harapan), kriteria BSH (Berkembang sesuai harapan) berpindah menjadi BSB (berkembang sesuai harapan) sehingga pada siklus III semua anak sudah mencapai kriteria BSB (Berkembang sangat Baik).

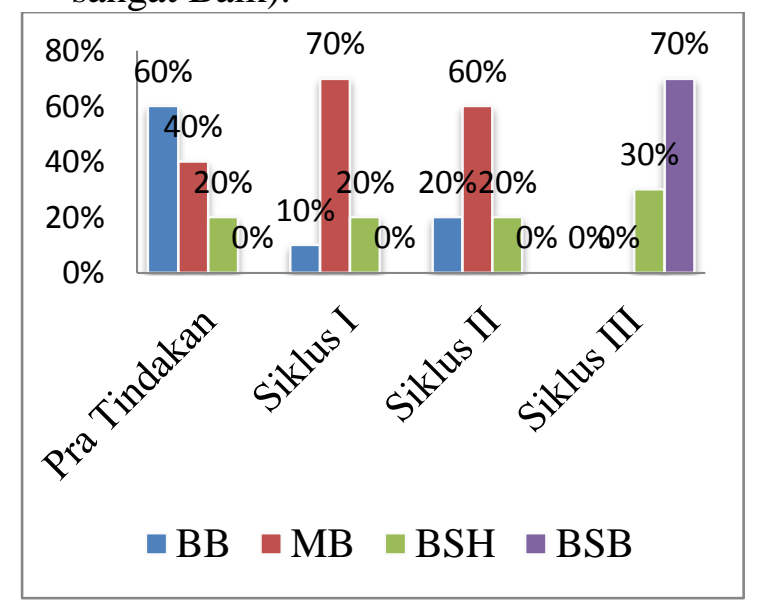

Gambar 4.8.

Diagram Perubahan Pra Tindakan - Siklus III Aspek Melakukan gerakan terkoordinasi secara terkontrol

Dari gambar 4.5. dapat diketahu kriteria BB (Belum berkembang) pada kondisi awal sebesar $60 \%$ (6 orang anak), siklus I sebesar $20 \%$ (2 orang anak), siklus II sebesar $10 \%$ (1 orang anak), sedangkan siklus III tidak ada satupun kriteria BB (Belum berkembang). Kriteria MB pada kondisi awal sebesar 40\% (4 orang anak), siklus I sebesar $60 \%$ (6 orang anak), siklus II sebasar 10\% (1 orang anak) sedangkan siklus III tidak ada satupun kriteria MB (Masih berkembang). Kriteria BSH (Berkembang sesuai harapan) pada kondisi awal tidak ada satupun kriteria BSH (Berkembang sesuai harapan), sedangkan siklus I sebesar $20 \% \quad$ (2 orang anak), siklus II sebesar $70 \%$ (7 orang anak), dan siklus III sebesar 30\% (3 orang anak). kriteria BSB (Berkembang sangat baik) pada kondisi awal, siklus I tidak ada satupun kriteria BSB (Berkembang sangat baik), siklus II sebesar 20\% (2 orang anak), dan siklus III sebesar $70 \%$ (7 orang anak). Dari data tersebut kemampuan motorik halus anak usia dini pada aspek melakukan gerakan terkoordinasi secara terkontrol mengalami peningkatan. Hal tersebut terlihat dari perubahan tiap kriteria, dari BB (Belum berkembang) sebagian berpindah menjadi MB (Masih berkembang) meskipun masih ada anak yang kriteria BB (Belum berkembang), dari MB (Masih berkembang) berpindah menjadi BSH (Berkembang sesuai harapan), kriteria BSH (Berkembang sesuai harapan) berpindah menjadi BSB (berkembang sesuai harapan) sehingga pada siklus III semua anak sudah mencapai kriteria BSH (Berkembang sesuai harapan) dan kriteria BSB (Berkembang sangat Baik).

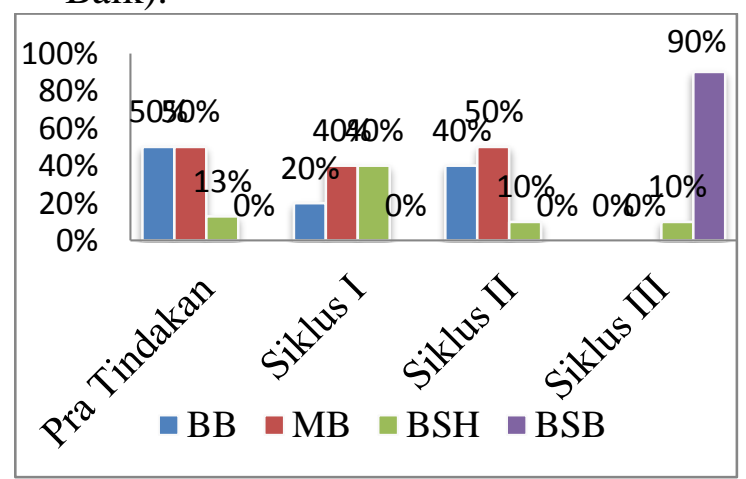

Gambar 4.9.

Diagram Perubahan Pra

Tindakan - Siklus III

Aspek Terampil dalam

Kecermatan dan Ketepatan

Dari gambar 4.6. dapat diketahui bahwa kriteria BB (belum berkembang) pada kondisi awal sebesar $50 \%$ (5 orang anak), siklus I sebesar $20 \%$ (2 orang anak), siklus II dan siklus III tidak ada satupun kriteria BB (Belum berkembang), Kriteria MB pada kondisi awal sebesar 50\% (5 orang anak), siklus I sebesar 40\% (6 orang anak), siklus II sebesar 20\% (2 orang anak) sedangkan pada siklus III tidak ada satupun kriteria MB (Masih berkembang). Kriteria BSH (berkembang sesuai harapan) pada kondisi awal tida ada satupun kriteria BSH (Berkembang sesuai harapan), sedangkan siklus I sebesar $40 \%$ (4 orang anak), siklus II sebesar 50\% (5 orang anak), dan siklus III sebesar $10 \%$ (1 orang anak). kriteria BSB (Berkembang sangat baik) pada kondisi 
awal dan siklus I tidak ada satupun kriteria BSB (Berkembang sangat baik), siklus II sebesar 10\% (1 orang anak), dan siklus III sebesar 90\% (9 orang anak). Dari data tersebut kemampuan motorik halus anak usia dini pada aspek terampil dalam kecermatan dan ketepatan. Hal tersebut terlihat dari perubahan tiap kriteria, dari BB (Belum berkembang) sebagian berpindah menjadi MB (Masih berkembang) meskipun masih ada anak yang kriteria BB (Belum berkembang), dari MB (Masih berkembang) berpindah menjadi BSH (Berkembang sesuai harapan), kriteria BSH (Berkembang sesuai harapan) berpindah menjadi BSB (berkembang sesuai harapan) sehingga pada siklus III semua anak sudah mencapai kriteria BSH (Berkembang sesuai harapan) dan kriteria BSB (Berkembang sangat Baik).

Berdasarkan penelitian

yang telah dilakukan dapat diketahui bahwa kegiatan meronce dapat meningkatkan kemampuan motorik halus anak usia dini, hal ini sejalan dengan penelitian skripsi Bakti Arum Mumpuni yang berjudul Peningkatan Keterampilan Motorik Halus Melalui Kegiatan Meronce Menggunakan Bahan Tanah Liat Pada Kelompok B TK Yayasan MAsyithoh Beran Bugel Kulon Progo Tahun .

\section{KESIMPULAN}

Berdasarkan hasil penelitian dan temuan di lapangan tentang “ Peningkatan Kemampuan Motorik Halus Anak Usia Dini melalui Kegiatan Meronce Menggunakan Manik-manik Pada Kelompok B2 Di TK AL- Hamid Kecamatan Kawalu Kota Tasikmlaya" dapat diperoleh kesimpulan sebagai berikut:

1. Kemampuan guru dalam membuat Rencana Pelaksanaan Pembelajaran Harian (RPPH) untuk meningkatkan kemampuan motorik halus anak kelompok B2 TK AlHamid melalui kegiatan meronce menggunakan manik-manik mengalami peningkatan pada setiap tindakan setelah melalui tahaptahap pelaksanaan pada penelitian tindakan kelas ini. Pada tindakan siklus I jumlah skor yang dicapai sebesar 10,8 dengan persentase $67,5 \%$. Pada tindakan siklus II jumlah skor yang dicapai sebesar 11,8 dengan persentase $73,8 \%$. Pada tindakan siklus III jumlah skor yang dicapai sebesar 14,1 dengan persentase $87,5 \%$.

2. Kemampuan guru dalam melaksanakan pembelajaran untuk meningkatkan kemampuan motorik halus anak usia dini pada kelompok B2 TK Al- Hamid melalui kegiatan meronce menggunakan manikmanik mengalami peningkatan pada setiap tindakan setelah melalui tahap-tahap pelaksanaan pada penelitian tindakan kelas ini. Pada tindakan siklus I jumlah skor yang dicapai sebesar 22 dengan persentase $39 \%$. Pada tindakan siklus II jumlah skor yang dicapai sebesar 45 dengan persentase $80 \%$. Pada tindakan siklus III jumlah skor yang dicapai sebesar 52 dengan persentase $93 \%$.

3. Kemampuan anak kelompok B2 TK Al- Hamid ketika meronce menggunakan manik-manik mengalami peningkatan pada setiap tindakan setelah melalui tahaptahap pelaksanaan pada penelitian ini. Pada siklus I indikator terampil dalam menggunakan jari-jemari tangan untuk melakukkan aktivitas dan terampil dalam menggerakkan jari-jemari tangan tidak ada satupun yang mencapai keberhasilan, sedangkan indikator terampil dalam menggerakkan kedua tangan yang mencapai keberhasilan sebanyak 2 anak dengan persenatse $20 \%$, indikator pengedalian gerak sebanyak 3 anak dengan persentase $30 \%$, indikator melakukkan gerakkan terkoordinasi secara terkontrol sebanyak 2 anak dengan persentase $20 \%$, dan indikator terampil dalam kecermatan dan ketepatan sebanyak 4 anak dengan persentase $40 \%$. Pada siklus II indikator terampil dalam menggunakan jari-jemari tangan untuk melakukkan aktivitas dan terampil dalam menggerakkan 
jari jemari tangan tidak ada satupun yang mecapai keberhasilan, sedangkan indikator terampil dalam menggerakkan kedua tangan yang mencapai keberhasilan sebanyak 6 anak dengan persenatse $60 \%$, indikator pengedalian gerak sebanyak 6 anak dengan persentase $60 \%$, indikator melakukkan gerakkan terkoordinasi secara terkontrol sebanyak 7 anak dengan persentase $70 \%$, dan indikator terampil dalam kecermatan dan ketepatan sebanyak 5 anak dengan persentase $50 \%$. Pada siklus III indikator terampil dalam menggunakan jari-jemari tangan untuk melakukkan aktivitas yang mencapai keberhasilan sebanyak 2 anak dengan persentase 20\%, indikator terampil dalam menggerakkan jari jemari tangan dan indikator terampil dalam menggerakkan kedua tangan tidak ada satupun yang mencapai keberhasilan , indikator pengedalian gerak sebanyak 2 anak dengan persentase $20 \%$, indikator melakukkan gerakkan terkoordinasi secara terkontrol sebanyak 3 anak dengan persentase $30 \%$, dan indikator terampil dalam kecermatan dan ketepatan sebanyak 1 anak dengan persentase $10 \%$.

\section{SARAN}

Untuk meningkatkan kualitas dalam peningkatan kemampuan motorik halus anak usia dini, peneliti menyampaikan beberapa saran sebagai berikut:

1. Dalam melaksanakan kegiatan peningkatan motorik halus anak usia dini melalui kegiatan meronce hendaknya guru memilih manikmanik yang dengan warna dan bentuk yang beragam pula agar anak lebih antusias mengikuti kegiatan.

2. Bagi peneliti selanjutnya yang tertarik dengan penelitian peningkatan motorik halus anak usia dini sebaiknya menggunakan alternatif bahan yang lain atau dengan kegiatan yang lain yang lebih beragam.

\section{DAFTAR PUSTAKA}

Arikunto, S, dkk. (2013). Prosedur Penelitian Suatu Pendekatan Praktik. Jakarta : PT Rineka Cipta.

Latif, Mukhtar, dkk. (2013). Oriantentasi Baru Pendidikkan Anak Usia dini. Jakarta: Prenadamedia Group.

Sukerti, M, N. (2013). Penerapan Metode Demonstrasi Berbantuan Meida Daun Pisang Untuk Meningkatkan motoric Halus Anak Melalui Kegiatan Mernganyam Pada Anak TK.Vol.8.No 1,hlm-2.

Effiana Yustriastien, Daisy Prawitasari dkk. (2009). Games Therapy untuk Kecerdasan Bayi dan Balita. Jakarta: Wahyu Media.

Mumpuni, A. B (2014). Peningkatan Keterampilan Motorik Halus Melalui Kegiatan Meronce Menggunakan Bahan Tanah Liat Pada Kelompok B TK Yayasan MAsyithoh Beran Bugel Kulon Progo. Skripsi: Universitas Negri Yogyakarta.

Peraturan Mentri Pendidikan dan Kebudayaan Republik Indonesia Nomor 137 Indonesia Tahun 2017.

Peraturan Pemeritahan Menteri Pendidikkan dan Kebudayaan Republik Indonesia Nomor 146 Tahun 2014.

Wiyani, N. A. dan Faith (2016) . Konsep Dasar PAUD. Yogyabkarta: Gaya Media

Djamarah, Syaiful Bahri dan Zain Awar. (2013). Strategi Belajar Mengajar. Jakarta : PT Rineka Cipta

Pedoman Karya Tulis Ilmiah Universitas Pendidikan Indonesia Tahun 2017

Sujiono, Y.N. (2013). Konsep Dasar Pendidikan Anak Usia Dini. Jakarta: Indeks

Beaty, J. J. (2013). Observasi

Perkembangan Anak Usia dini. Jakarta:

Kencana 
Susanto. Pendidikkan Anak Usia Dini. Jakarta: PT Bumi Aksara

Arifah, N. A. (2017). Penelitian Tindakkan Kelas \& Karya Tulis Ilmiah Untuk Guru. Yogyakarta: Araska.

Rahayu, T. A. (2016). Peningkatan Kemampuan Motorik Halus Melalui Kegiatan Meronce Bahan Alam Pada Anak Kelmpok B TK PKK Selodono Tahun Pelajaran 2015/2016. (Jurnal 2016 Universitas Nusantara PGRI Kediri).ss

Suyadi, dan Ulfah Maulidya. (2015).

Konsep Dasar Paud. Bandung : PT Remaja Rosdakaya.

Pamadhi, dan Sukandi Evan. (2015). Seni Keterampilan Anak. Bandung : Penerbit Universitas Terbuka.

Soetjiningsih, Cristiana Hari. (2012). Perkembangan Anak Sejak Pembuatan Sampai Dengan Kanak-Kanak Akhir. Jakarta : PRENADA.

Sumantri.(2005) Model Pengembangan Keterampilan Motorik Anak Usia Dini. Jakarta: Departemen Pendidikan Nasional. Direktorat Jenderal Pendidikan Tinggi. Direktorat Pembinaan Pendidikan Tenaga Kependidikan Dan Ketenagaan Perguruan Tinggi.

Mulyati, A. (2014). Peningkatan

Keterampilan Motorik Halus

Melalui Origami Pada Anak kelompok A TK Kusuma Baciro Gondokusuman Yogyakarta. Skripsi, 25.

Fauziyah, Fitriani. (2017). Penggunaan Media Kartu Kata Bergambar untuk Meningkatkan Penguasaan Kosakata Bahasa Sunda Anak Usia Dini Pada Kelompok B di TK PGRI Cibeureum. (Skripsi, Universitas Pendidikan Indonesia Kampus Tasikmalaya, 2016, tidak diterbitkan).
Arikunto, S, dkk. (2013). Prosedur Penelitian Pendekatan Praktik. Jakarta: PT Rineka Cipta.

Trianto. (2011). Panduan lengkap Penelitian Tindakan Kelas. Jakarta: Prestasi Pustaka.

Priatna, Y. S. (2008). Metode Penelitian Pendidikan. Bandung: TSAbitA

Sugiyono. (2015). Metode Penelitian. Bandung: Anggota Ikatan Penerbit Indonesia (IKAPI). 